\title{
Wing length as a predictor of body size in the Willow Tit Poecile montanus
}

\author{
Olav Hogstad
}

Norwegian University of Science and Technology, Section of Natural History, NO-7491 Trondheim, Norway

E-mail: Olav.Hogstad@vm.ntnu.no

\begin{abstract}
In a subalpine mixed forest in central Norway, I measured the wing length, tail length and tarsus length and recorded the body mass of 48 male and 43 female first-year Willow Tits Poecile montanus. Some of these were retrapped in the following years and measured again after they had moulted. The wing length of first-year birds was significantly correlated (Pearson) with tail length (males: $\mathrm{p}<0.01$; females: $\mathrm{p}<0.05$ ) and tarsus length (males: $\mathrm{p}<0.05$; females: $\mathrm{p}<0.05$ ) but not with body mass. After their postnuptial moult in July-September, i.e. from their first-year to adult stage, the mean wing length of males increased significantly: $0.82 \mathrm{~mm}$ from their first to their second year and $0.37 \mathrm{~mm}$ from their second to their third year. Also the mean wing length increase in females was marked from first to second year $(0.24 \mathrm{~mm})$, but not for the following years. In adult Willow Tits, i.e. two years or older, the wing length was significantly correlated with only tarsus length $(p<0.05)$ in males and tail length $(p=0.01)$ in females. Thus, while wing length apparently is an appropriate measure of body size of first-year Willow Tits, it seems to give an uncertain reflection of the size in adult birds.
\end{abstract}

Key words: Wing length increase, Willow Tit, Poecile montanus

\section{INTRODUCTION}

Size is a characteristic which is assumed to have been selected for by environmental selective factors (e.g. Lehikoinen 1986). Ecogeographic trends in size are the rule in many birds (Peters 1983, Harvey \& Pagel $1991)$ and it is suggested that overwinter mortality is size dependent (e.g. Perrins 1965, Lehikoinen 1986, but see Garnet 1981); large size may be advantageous because energy loss is proportionately less from a larger body (e.g. Calder 1974) and large individuals in many species are dominant over smaller ones (Järvi \& Bakken 1984, Hogstad 1987, Koivula \& Orell 1988).

Wing length is often used as a measure of overall size (e.g. Lehikoinen 1986, Svensson 1992, Gosler et al. 1998) despite the fact that the structure of wing varies independently of size, that feathers wear with time (Svensson 1992), wing length depends on age (Gosler et al. 1998, Hogstad 1987) and wing length may vary between years (Lehikoinen 1986, Hogstad unpubl.).

In the present paper I examine the relationships between wing length, tail length, tarsus length and body mass of Willow Tits Poecile montanus to investigate whether the length of the wing can be used as a measure of the birds' size. Moreover, the same individuals were measured again in the next two to four years to see if the findings may be applied irrespective of age.

\section{MATERIAL AND METHODS}

The study was made in a subalpine mixed forest (altitude c. 600m) composed of Scots Pine Pinus sylvestris and Downy Birch Betula odorata in about equal numbers in Budal, central Norway $\left(62^{\circ} 50^{\prime} \mathrm{N}, 10^{\circ} 25^{\prime} \mathrm{E}\right)$ during the years 1986-1993.

The tits studied were caught in October-November, and individually colour-ringed, sexed (Haftorn 1982, Hogstad 1987) and aged (first-year vs. older birds; see Laaksonen \& Lehikoinen 1976). The sex of some individuals was later verified during breeding. Totally 48 males and 43 females, all first-year birds (juveniles) were caught in feeder-traps, and some of these birds were later retrapped and measured again in the following years (Table 1). The birds were weighed with a Pesola spring-balance, generally with an accuracy of $0.2 \mathrm{~g}$, and their wing and tail lengths were measured to the nearest $0.5 \mathrm{~mm}$. Only weight values made between 1100-1300 hours were recorded, since bodyweight varies appreciably throughout the day (Haftorn 1992, Ekman \& Lilliendahl 1993, Koivula et al. 2002). The folded wing was flattened against a ruler; their primaries were straightened, so as to give the maximum length. Tail length was measured from the base of the central tail feathers to the tip of the longest feather. The wing and tail lengths were measured on birds after their moulting. Yearling Willow Tits do not moult their 
Table 1. Number of Willow Tits measured in their first year. The same individuals were later measured again when two to four years old.

\begin{tabular}{llcccc}
\hline & & Wing & Tail & Tarsus & Mass \\
\hline First year & Males & 48 & 48 & 30 & 48 \\
& Females & 43 & 43 & 39 & 43 \\
Second year & Males & 42 & 28 & 8 & 27 \\
& Females & 35 & 24 & 9 & 23 \\
Third year & Males & 16 & 7 & 5 & 10 \\
& Females & 8 & 3 & 2 & 8 \\
Fourth year & Males & 6 & 1 & 3 & 4 \\
& Females & 5 & 1 & 1 & 4 \\
\hline
\end{tabular}

primaries or secondaries until the postnuptial moult of the following summer (Orell 1983, Svensson 1992). Tarsus length was measured to the nearest $0.05 \mathrm{~mm}$ using the standard method as described by Svensson (1992).

\section{RESULTS}

Males in their first year were larger than females in all measurements taken (Table 2), and the variation in their wing lengths (coefficient of variation, $\mathrm{CV}$ : males: $1.44 \%$; females: $1.23 \%$ ) and tarsus length (males: $2.47 \%$; females: $0.68 \%$ ) were higher.

Wing length was significantly correlated (Pearson) with tail length and tarsus length for both sexes (Table 3). Moreover, tail length was correlated with tarsus length in males but not in females. However, in adult birds (two years or older), male wing length was not significantly correlated with tail length $(\mathrm{r}=0.24$, $\mathrm{p}=0.16)$ but with tarsus length $(\mathrm{r}=0.52, \mathrm{p}<0.05)$. In adult females, wing length was significantly correlated with tail length $(\mathrm{r}=0.48, \mathrm{p}=0.01)$ but not with tarsus lengh $(r=0.11, p=0.74)$. Thus, wing length apparently is a better predictor of body size of first year birds than of older Willow Tits.

The mean wing length of males increased by 0.82 $\mathrm{mm}$ from their first to their second year (juvenile to adult; Paired-sample t-test, $\mathrm{t}=14.86, \mathrm{df}=40, \mathrm{p}<0.001$ ) and 0.37 $\mathrm{mm}$ from their second to their third year $(\mathrm{t}=2.52, \mathrm{df}=15$, $\mathrm{p}=0.023$ ), whereas the increase from third to fourth year was not significant $(0.14 \mathrm{~mm}$; Figure 1$)$. Also the mean wing length increase in females was marked from first to second year $(0.24 \mathrm{~mm} ; \mathrm{t}=4.14, \mathrm{df}=33, \mathrm{p}<0.001)$, but not for the following years $(p>0.05)$. Thus, the wing length of males apparently increases also after the second moult in males. The wing length increase from the first to the second year was greater in males than in females $(\mathrm{t}=6.67, \mathrm{p}<0.001)$.

Both sexes increased their tail length after their first moulting (males: $0.41 \mathrm{~mm}, \mathrm{t}=3.32, \mathrm{df}=27, \mathrm{p}<0.001$; females: $0.31 \mathrm{~mm}, \mathrm{t}=3.72, \mathrm{df}=23, \mathrm{p}=0.001$ ). The mean wing length and tarsus length of first year males varied annually (One-way ANOVA, wing: $\mathrm{F}_{6,47}=5.773$, $\mathrm{p}<0.001$; tarsus: $\mathrm{F}_{6,29}=2.655, \mathrm{p}<0.05$ ), but not in tail length or body mass. No such variation was found for first year females. Although both sexes showed some increase in their mean body mass after their postnuptial moult, the differences were not significant.

Thus, the results indicate that wing length may be an appropriate measure of body size of first-year Willow Tits as it correlates with tail and tarsus lengths, whereas it seems to give an uncertain reflection of size in adult birds.

\section{DISCUSSION}

The wing length obviously was the best predictor of

Table 2. Measurements of first-year (juvenile) Willow Tits, their wing length, tail length and tarsus length and body mass.

\begin{tabular}{lccccccc}
\hline & \multicolumn{3}{c}{ Males } & & \multicolumn{3}{c}{ Females } \\
\cline { 2 - 3 } & Range & Mean \pm SD & $\mathrm{n}$ & & Range & Mean \pm SD & $\mathrm{n}$ \\
\hline Wing length $(\mathrm{mm})$ & $65-69$ & $66.63 \pm 0.96$ & 48 & & $61-64$ & $62.79 \pm 0.77$ & 43 \\
Tail length $(\mathrm{mm})$ & $56-60$ & $58.27 \pm 0.72$ & 48 & & $54-57$ & $55.21 \pm 0.73$ & 43 \\
Tarsus length $(\mathrm{mm})$ & $15.5-17.2$ & $16.61 \pm 0.41$ & 30 & & $16-16.5$ & $16.29 \pm 0.11$ & 39 \\
Body mass $(\mathrm{g})$ & $11-13$ & $11.90 \pm 0.49$ & 48 & & $9.8-11.8$ & $10.78 \pm 0.43$ & 43 \\
\hline
\end{tabular}


Table 3. Intercorrelation matrix for the different characteristics of the first-year and adult (two years or older) Willow Tits studied. Asterisks denote significance levels in Pearson correlation analyses, twotailed $(* *=\mathrm{p}<0.01, *=\mathrm{p}<0.05)$.

\begin{tabular}{|c|c|c|c|c|c|c|}
\hline & \multicolumn{3}{|c|}{ Males } & \multicolumn{3}{|c|}{ Females } \\
\hline & Tail & Tarsus & Mass & Tail & Tarsus & Mass \\
\hline \multicolumn{7}{|l|}{ First year: } \\
\hline Wing length & $0.46^{* *}$ & $0.46^{*}$ & 0.16 & $0.32 *$ & $0.37 *$ & 0.11 \\
\hline Tail length & & $0.40 *$ & 0.23 & & 0.01 & 0.12 \\
\hline Tarsus length & & & 0.30 & & & 0.06 \\
\hline \multicolumn{7}{|l|}{ Adults: } \\
\hline Wing length & 0.24 & $0.52 *$ & 0.04 & $0.48 * *$ & 0.11 & -0.01 \\
\hline Tail length & & -0.06 & 0.28 & & 0.04 & 0.20 \\
\hline Tarsus length & & & $0.70 * *$ & & & 0.18 \\
\hline
\end{tabular}

body size among the four characters examined in Willow Tits. The tarsus length, however, gave a less convincing measure of overall size. Similarly, Garnet (1981) found that even if tarsus length may be a good measure of body size for Great Tit Parus major nestlings, it may not be the case for full-grown birds.

The variation in wing length among years, as found for first-year males in the present study, may be a result of differences in the food situation of their parents just

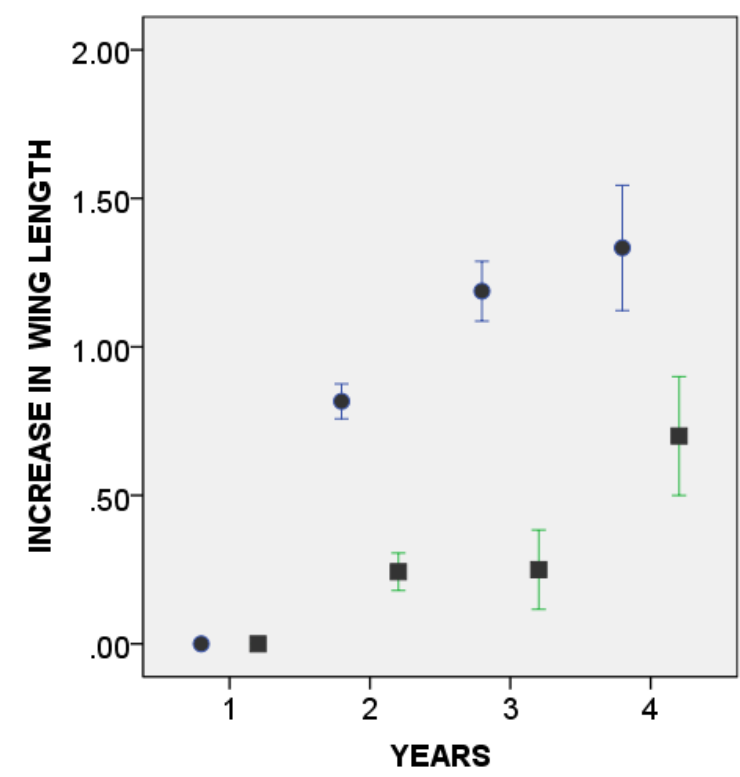

Figure 1. Mean yearly increase in wing length $(\mathrm{mm} \pm 1 \mathrm{SE})$ of male (circles) and female (squares) Willow Tits. Year $=1$ denotes first-year birds. The increase between first and second year is statistically significant in a two-tailed Paired-sample t-test for both sexes, whereas the increase between the second and the third year is significant only for the males. before or during the nesting period (e.g. Thessing 1999, Hogstad unpubl.). The condition of the breeding pair depends on the prevailing conditions and their ability to find food, and size reduction has been found in Willow Tit broods to match energy expenditure to the amounts of food which the parents can provide (Orell 1983). Moreover, the averages for wing length and tail length were greater for Willow Tit chicks that were hatched early than later (Orell 1983).

The greater increase in wing length of males than of females may be because it is more important for males than for females to be large and high-ranked in the winter flocks (e.g. Hogstad 1992). The most dominant of the juvenile males in winter flocks have a higher probability of settling in an area than the subordinates and thus increase their winter survival (Hogstad 1999).

Body mass scored less as a predictor of body size, probably because of the particularly social behavior of the species: after a short postnatal dispersal period most juvenile Willow Tits settle around the nucleus of an adult mated pair that occupies a year-round territory. An early settlement is important for the dominance rank order (Hogstad 1990a), because the earliest become the dominant of the juveniles (e.g. Hogstad 1990b, Thessing 1999). Although most juvenile dominants have larger wing lengths than subordinates, the opposite may occasionally occur if the latter had settled earliest. Since high rank Willow Tits carry lower energy reserves than subordinates (Ekman \& Lilliendahl 1993) and also increase their weight by fat difference during the day (Koivula et al. 1995), body mass may be a less reliable predictor of body size. Moreover, Parus species vary in weight seasonally (e.g. Lehikoinen 1986).

To conclude, if only one measurement can be taken of Willow Tits in the field, I agree with Gosler et al. (1998) who concluded that wing length should be used since it is the best size predictor for many passerine species. 
Acknowledgements. I am grateful to Arild Breistøl and Thor Harald Ringsby for comments on an earlier version of the manuscript.

Sammendrag. Vingelengde som prediktor for kroppsstørrelse hos granmeis. Vingelengde, stjertlengde og tarslengde samt kroppsvekt ble registrert hos 48 hanner og 43 hunner av juvenile $(1 \mathrm{~K})$ granmeis i felt. Flere av disse ble gjenfanget og målt $i$ de følgende tre årene. Vingelengden hos hanner økte gjennomsnittlig $0.82 \mathrm{~mm}$ fra første til andre år og $0.37 \mathrm{~mm}$ fra andre til tredje år. Hos hunner var økningen fra første til andre år $0.24 \mathrm{~mm}$. Vingelengden hos juvenile hanner og hunner var klart korrelert med stjert- og tarslengde, men ikke med kroppsvekten. Hos adulte (to år eller eldre) var vingelengden korrelert bare med tarslengden hos hanner og stjertlengden hos hunner. Vingelengden synes derfor å være en god prediktor for kroppsstørrelse hos juvenile granmeiser, mens den er mindre sikker for adulte.

\section{REFERENCES}

Calder, W.A. 1974. Consequence of body size for avian energetics. Pp. 86-144 in Avian energetics (Painter, R.A., ed.). Nuttall Ornithol. Club. 15, Cambridge, Massachusetts.

Ekman, J. \& Lilliendahl, K. 1993. Using priority to food access: fattening strategies in dominance-structured Willow Tit (Parus montanus) flocks. Behav. Ecol. 4: 232-238.

Garnet, M.C. 1981. Body size, its heritability and influence on juvenile survival among Great Tits, Parus major. Ibis 123: 31-41.

Gosler, A.G., Greenwood, J.J.D., Baker, J.K. \& Davidson, N.C. 1998. The field determination of body size and condition in passerines: a report to the British Ringing Committee. Bird Study 45: 92-103.

Haftorn, S. 1982. Variation in body measurements of the Willow Tit Parus montanus, together with a method for sexing live birds and data on the degree of shrinkage in size after skinning. Fauna norv. Ser. C, Cinclus 5: 16-26.

Haftorn, S. 1992. The diurnal body weight cycle in titmice Parus spp. Ornis Scand. 23: 435-443.

Harvey, P.H. \& Pagel, M.D. 1991. The Comparative Method in Evolutionary Biology. Oxford University Press, Oxford.

Hogstad, O. 1987. Social rank in winter flocks of Willow Tits Parus montanus. Ibis 129: 1-9.

Hogstad, O. 1990a. Dispersal date and settlement of juvenile
Willow Tits Parus montanus in winter flocks. Fauna norv. Ser. C. Cinclus 13: 49-55.

Hogstad, O. 1990b. Winter floaters in Willow Tits Parus montanus - a matter of choice or making the best of a bad situation? Pp. 415-421 in Population biology of passerine birds (Blondel, J., Gosler, A., Lebreton, J.-D. $\&$ McCleery, R. eds.). Springer-Verlag, Berlin.

Hogstad, O. 1992. Mate protection in alpha pairs of wintering willow tits, Parus montanus. Anim. Behav. 43: 323-328.

Hogstad, O. 1999. Territory acquisition during winter by juvenile Willow Tits Parus montanus. Ibis 141: 615-620.

Järvi, T. \& Bakken, M. 1984. The function of the variation in the breast stripe of the Great Tit (Parus major). Anim. Behav. 32: 590-596.

Koivula, K. \& Orell, M. 1988. Social rank and winter survival in the willow tit Parus montanus. Ornis Fennica 65: 114-120.

Koivula, K., Orell, M. \& Lahti, K. 2002. Plastic daily fattening routines in Willow Tits. J. Anim. Ecol. 71: 816-823.

Koivula, K., Orell, M., Rytkönen, S. \& Lahti, K. 1995. Fatness, sex and dominance; seasonal and daily weight changes in wintering Willow Tits. J. Avian. Biology 26: 209-216.

Laaksonen, M. \& Lehikoinen, E. 1976. Age determinations of Willow and Crested Tit Parus montanus and $P$. cristatus. Ornis Fennica 53: 9-14.

Lehikoinen, E, 1986. Winter ecology of passerines: significance of weight and size. Ph.D.thesis, University of Turku, Finland.

Orell, M. 1983. Breeding and mortality in the Great Tit Parus major and the Willow Tit P. montanus. Ph.D.thesis, University of Oulu, Finland.

Peters, R.H. 1983. The ecological implications of body size. Cambridge University Press, Cambridge.

Perrins, C.M. 1965. Population fluctuations and clutch size in the Great Tit Parus major L. J. Anim. Ecol. 34: 601-647.

Svensson, L. 1992. Identification guide to European passerines. Stockholm, Sweden.

Thessing, A. 1999. Growth and heritability of size traits of Willow Tit Parus montanus nestlings - a supplementary feeding experiment. Ornis Fennica 76: 107-114.

Received 3 May 2011, accepted 4 November 2011 